\title{
Pengaruh Motivasi terhadap Kinerja Karyawan PT Brawijaya Utama Palembang
}

\author{
Muhammad Dede Septiadi $^{1)}$, Luis Marnisah ${ }^{2)}$, Susi Handayani ${ }^{3)}$ \\ 1), 2), 3) Universitas Indo Global Mandiri \\ Email: mdedeseptiadi14@gmail.com ${ }^{1)}$,luismarnisah@uigm.ac.id²),susihandayani25@yahoo.co.id ${ }^{3)}$
}

\begin{abstract}
Abstrak
Penelitian ini dilakukan untuk menginvestigasi pengaruh motivasi terhadap kinerja karyawan di PT Brawijaya Utama Palembang. Teknik pengumpulan data dilakukan dengan menyebarkan kuesioner yang berisi bertanyaan sebanyak 24. Metode analisis data menggunakan regresi linear sederhana. Hasil analisis regresi menjelaskan bahwa persamaan motivasi terhadap kinerja karyawan yaitu $Y=3,326+0,653 X$. Hal ini menyatakan bahwa jika nilai motivasi adalah nol maka nilai kinerja karyawan adalah sebesar 3,326. Setiap kenaikan nilai motivasi sebesar 1, maka akan menaikkan kinerja karyawan sebesar 0,653. Berdasarkan uji t, nilai t hitung adalah 9,164 dan nilai t tabel adalah 1,667. Nilai hitung lebih besar dari nilai t tabel yaitu 9,164 > (1,667) dengan nilai sig 0,000 (dibawah 0,05). Ini mengindetifikasikan bahwa variabel motivasi berpengaruh signifikan terhadap kinerja karyawan. Nilai koefisien determinasi (R2) diperoleh sebesar 0,549, artinya besarnya sumbangan pengaruh motivasi terhadap kinerja karyawan PT. Brawijaya Utama Palembang adalah 54,9\%, sedangkan sisanya 45,1\% dipengaruhi oleh variabel lain yang tidak teliti dalam penelitian ini.
\end{abstract}

Keywords: motivasi, kinerja karyawan, manajemen sumber daya manusia, studi keperilakuan

\section{Pendahuluan}

Sumber daya manusia merupakan modal yang paling penting untuk mencapai tujuan perusahan, kunci kesuksesan sebuah perusahaan bukan hanya pada teknologi dan ketersedianya dana saja, faktor manusia dalam suatu perusahaan memegang peranan yang sangat penting, tenaga kerja memiliki potensi yang besar untuk menjalankan aktivitas perusahaan.

Perusahaan dan karyawan merupakan dua hal yang saling membutuhkan jika karyawan berhasil membawa kemajuan bagi perusahaan, keuntungan yang diperoleh akan dipetik oleh kedua belah pihak. Bagi karyawan keberhasilan merupakan aktualitas potensi diri sekaligus peluang untuk memenuhi kebutuhan hidupnya, sedangkan bagi perusahaan, keberhasilan merupakan sarana menuju pertumbuhan dan perkembangan perusahaan.

Motivasi dapat dipandang sebagai perubahan energy dalam diri seseorang yang ditandai dengan munculnya feeling, dan didahuluhi dengan tanggapan terhadap adanya tujuan. Motivasi adalah dorongan dasar yang menggerakan seseorang atau keinginan untuk mencurahkan segala tenaga karena adanya suatu tujuan. Seperti yang dikemukakan oleh Mangkunegara (Mangkunegara, 2011, 2014, p. 61, 2015) motivasi merupakan kondisi atau energi yang menggerakan diri karyawan terarah atau tertuju untuk mencapai tujuan perusahaan. Sikap mental karyawan yang positif terhadap situasi kerja itulah yang memperkuat motivasi kerjanya untuk mencapai kinerja yang maksimal, faktor pendorong dari seseorang untuk melakukan suatu aktivitas tertentu pada umumnya adalah kebutuhan serta keinginan orang lain. Tiga unsur yang merupakan kunci dari motivasi yaitu upaya, tujuan organisasi, dan kebutuhan. Motivasi muncul dari dalam diri manusia karena dorongan oleh adanya unsur suatu tujuan. Tujuan menyangkut soal kebutuhan 
dapat dikatakan bahwa tidak ada suatu motivasi apabila tidak dirasakan adanya suatu kebutuhan.

Kinerja pada umumnya diartikan sebagai kesuksesan seseorang didalam, melaksanakan suatu pekerjaan. Kinerja karyawan merupakan hasil kerja yang dicapai seseorang dalam melaksanakan tugas-tugas yang dibebankan kepadanya. Kinerja karyawan meliputi kualitas dan kuantitas output serta keandalan dalam bekerja. Karyawan dapat dikatakan bekerja dengan baik bila memiliki kinerja yang tinggi sehingga dapat menghasilkan kerja yang baik pula. Kinerja adalah hasil dari suatu proses yang mengacu dan diukur selama periode waktu tertentu berdasarkan ketentuan atau kesepakatan yang telah ditetapkan sebelumnya (Edison, Anwar, \& Komariyah, 2016, p. 190). Kinerja adalah suatu hasil kerja yang dicapai seorang dalam melaksanakan tugas yang dibebankan kepada yang didasarkan atas kecakapan, pengalaman kesungguhan serta waktu (Riyadi, 2011).

PT Brawijaya Utama Palembang diawali dengan didirikannya CV Lematang pada 06 November 1989, beralamat di Jln. Veteran No. 3433E, Palembang, Sumatera Selatan. Sebagai perusahan nasional, awal mula usaha yang dijalankan adalah sebagai supplier/pemasok untuk usaha tambang PT Bukit Asam, di Muara Enim, Sumatera Selatan. Adapun barang-barang yang dipasok adalah meliputi alat-alat teknik, spare part mesin, alat tulis kantor, alat-alat laboratorium, dan rental alat berat. Selanjutnya perusahan mengembangkan usahanya sebagai penyedia Balai Penelitian Sembawa, di mana perusaahan menyuplai ke Balai Penelitian Sembawa berupa peralatan perkebunan, bahan bangunan dan bahan kimia. Seiring dengan perkembangan usaha, perusahan terus melakukan eksepansi usaha yang meliputi pekerjaan sipil/kontraktor meliputi pembangunan perumahan, renovasi bangunan, pembuatan jalan dan transportasi angkutan dump truk. Dengan berjalannya waktu dan kepercayaan serta dukungan dari pelanggan, pada akhir tahun 2013 dibentuklah PT Brawijaya Utama Palembang. Berdasarkan latar belakang masalah yang telah diuraikan maka rumusan masalah pada penelitian ini adalah: Bagaimana pengaruh motivasi terhadap kinerja karyawan pada PT Brawijaya Utama Palembang?

\section{Tinjauan Pustaka}

\subsection{Kinerja Karyawan}

Kinerja adalah hasil kerja secara kualitas dan kuantitas yang dicapai oleh seseorang karyawan dalam melaksanakan tugasnya sesuai dengan tanggung jawab yang di berikan kepadanya. Menurut Helfert yang dialihbahasakan oleh Zainal, dkk. (2016, p. 604) kinerja adalah suatu tampilan keadaan secara utuh atas perbuatan selama periode waktu tertentu, merupakan hasil atau prestasi yang dipengaruhi oleh kegiatan operasional perusahaan dalam memanfaatkan sumber-sumber daya yang dimiliki. Berdasarkan pendapat diatas dapat disimpulkan bahwa kinerja karyawan merupakan hasil dan keluaran yang dihasilkan oleh seorang karyawan sesuai dengan yang baik adalah salah satu faktor yang sangat penting dalam upaya instansi untuk meningkatkan produktivitas. Kinerja merupakan indikator dalam menentukan bagaimana usaha untuk mencapai tingkat produktivitas yang tinggi dalam suatu organisasi atau instansi.

\subsection{Faktor-Faktor yang Memengaruhi Kinerja}

Faktor yang mempengaruhi kinerja menurut Sutrisno Edy (2014, p. 153) mengemukakan adanya dua faktor yang mempengaruhi kinerja yaitu, faktor disiplin individu dan lingkungan, faktor-faktor individu yang dimaksud adalah: 
1. Usaha yang menunjukan sejumlah sinergi fisik dan mental yang digunakan dalam menyelenggarakan gerakan tugas.

2. Abilites, yaitu sifat-sifat personal yang diperlukan untuk melaksanakan suatu tugas.

\subsection{Penilaian Kinerja}

Perusahan dapat mengetahui seorang karyawan mampu meningkatkan kinerja atau tidak dapat dilakukan dengan penilaian kerja. Menurut Sedarmayati (2013, p. 261), penilaian kinerja adalah uraian sistematik tentang kekuatan/kelebihan dan kelemahan yang berkaitan dengan pekerjaan seseorang atau kelompok. Dalam bukunya Manajemen Sumber Daya Manusia, Hasibuan (2012, p. 91), menyatakan bahwa seorang penilaian yang baik harus memiliki syarat-syarat sebagai berikut:

1. Untuk mendapatkan peniliain yang jujur, adil, dan objektif maka penilaian haruslah dilakukan orang yang mengerti tentang faktor-faktor yang menjadi indikator penilaian.

2. Penilaian harus tegas dan hendaknya mendasarkan penilaiannya pada benar atau salah terhadap unsur-unsur yang dinilai sehingga penilainnya jujur, adil dan objektif.

3. Penilaian harus mempunyai kewenagan formal supaya mereka dapat melaksanakan tugasnya dengan baik.

\subsection{Motivasi}

Kata motivasi (motivation) kata dasarnya adalah motif (motive) yang berarti dorongan, sebab

atau alasan seseorangan melakukan sesuatu. Motivasi merupakan kondisi yang mendorong atau menjadi sebab seseorang melakukan suatu perbuatan/kegiatan ulang berlangsung seacara sadar. Menurut Hasibuan (2013, p. 143) mengatakan bahwa motivasi kerja adalah pemberian daya penggerak yang menciptakan kegairahan kerja seseorang agar mereka mau bekerja sama, bekerja efektif, dan terintegrasi dengan segala daya upayanya untuk mencapai kepuasaan. Motivasi merupakan kondisi atau energi untuk menggerakan diri karyawan yang terarah atau yang tertuju untuk mencapai tujuan organisasi perusahan. Sikap mental karyawan yang pro dan positif itulah yang memperkuat motivasi kerjanya untuk mencapai kinerja maksimal.

\subsection{Hubungan Motivasi dengan Kinerja}

Motivasi kerja dan kinerja karyawan adalah dua hal yang berbeda, akan tetapi keduanya memiliki keterkaitan dalam organisasi. Motivasi kerja merupakan salah satu dari sekian banyak yang dapat mempengaruhi kinerja karyawan. Motivasi digunakan sebagai alat penggerak seorang individu untuk melakukan tindakan dalam pelaksanaan kinerja.

Dari rumusan diatas memberikan gambaran yang cukup jelas mengenai pentingnya seorang pemimpin mengupayakan agar karyawan melaksanakan tugas dengan hasil yang memuaskan. Karena pada dasarnya setiap karyawan memiliki kemampuan sesuai dengan pengetahuan, keterampilan, dan kompetensi yang berbeda.

\subsection{Kerangka Pemikiran}

Dalam penelitian ini diharapkan dapat dijelaskan bahwa pengaruh motivasi kerja terhadap kinerja karyawan pada PT Brawijaya Utama Palembang dapat memberikan gambaran mengenai pengaruh motivasi terhadap kinerja karyawan yang dapat dijadikan pegangan dalam penelitian seperti gambaran berikut: 
Gambar 1. Kerangka Pemikiran

\begin{tabular}{|c|}
\hline $\begin{array}{c}\text { Motivasi } \\
(\mathrm{X})\end{array}$ \\
$\begin{array}{c}\text { Kinerja Karyawan } \\
(\mathrm{Y})\end{array}$ \\
\hline
\end{tabular}

Dari kerangka pemikiran di atas dapat dijelaskan bahwa yang menjadi variabel independen (variabel bebas) adalah motivasi (X) dan yang menjadi variabel dependen (variabel terikat) adalah kinerja karyawan (Y).

\subsection{Hipotesis}

Dari rumusan masalah dan kerangka pemikiran maka dapat dibuat hipotesis sebagai berikut:

1. Ho diduga motivasi tidak berpengaruh terhadap kinerja karyawan PT Brawijya Utama Palembang.

2. Ha diduga motivasi berpengaruh terhadap kinerja karyawan PT Brawijaya Utama Palembang.

\section{Metode}

\subsection{Ruang Lingkup Penelitian}

Penelitian ini membahas masalah yang berkaitan dengan pengaruh motivasi terhadap kinerja karyawan pada PT Brawijaya Utama Palembang. Dengan penelitian ini apakah pengaruh motivasi terhadap kinerja karyawan berpengaruh secara signifikan.

\subsection{Populasi dan Sampel}

Populasi adalah keseluruhan yang terdiri atas objek atau subjek yang mempunyai karakteristik dan kualitas tertentu yang ditetapkan oleh peneliti untuk diteliti dan kemudian ditarik kesimpulannya. Sebuah perusahan yang akan di teliti adalah suatu populasi, apabila perusahan memiliki sejumlah karyawan atau subjek dan objek lainnya.

Bila populasi besar penelitian tidak mungkin mengambil semua untuk penelitian maka penelitian dapat menggunakan sampel yang diambil dari populasi. Sampel pada penelitian ini berjumlah 71 orang.

\subsection{Definisi Pengukuran Variabel}

Sesuatu hal yang berbentuk apa saja yang ditetapkan oleh penelitian untuk dipelajari sehingga diperoleh informasi tentang hal tersebut dan kemudian ditarik kesimpulannya. Adanya jenisjenis variabel tersebut adalah sebagai berikut: variabel independen/bebas (Variabel X). Variabel independen merupakan variabel yang dipengaruhi atau yang menjadi sebeb perubahannya atau timbulnya variabel dependen. Variabel bebas dalam penelitian ini adalah motivasi (X). Variabel dependen merupakan variabel yang dipengaruhi atau akibat,karena adanya variabel bebas. Dalam penelitian ini yang menjadi variabel dependen yaitu kinerja karyawan (Y).

\subsection{Teknik Analisis Data}

Alat analisis yang dipergunakan adalah regresi linier sederhana dan uji-t. Namun demikian, sebelum dilakukan analisis terlebih dahulu akan dilakukan pengukuran kuesioner sebagai alat 
pengumpulan data dengan uji validitas dan uji realibilitas.

\section{Pembahasan}

Dari hasil penelitian yang telah dilakukan mengenai pengaruh variabel $\mathrm{X}$ (motivasi) terhadap variabel Y (kinerja karyawan) PT Brawijaya Utama Palembang. Dari hasil analisis deskriptif responden yang menjawab pertanyaan pada kuesioner didapat responden paling menyetujui menjawab setuju (S) dan sangat setuju (SS).

Untuk mengetahui hasil uji validitas penelitian ini, menunjukkan bahwa semua pertanyaan yang telah disebar dinyatakan valid, karena nilai $r$ hitung $>r$ tabel sebesar 0,196 . sehingga semua butir pertanyaan yang diberikan kepada responden pada masing-masing variabel dinyatakan valid. Dari hasil uji reliabilitas menunjukkan semua koefisien reliable di atas 0,6 diperoleh dari variabel motivasi $(\mathrm{X})$ dan variabel kinerja $(\mathrm{Y})$ hal ini menunjukkan bahwa pertanyaan dalam kuesioner terbukti reliabel.

Hasil uji regresi sederhana yang telah dilakukan dan hasil konstanta adalah sebesar 3,326, menyatakan bahwa jika variabel motivasi $(\mathrm{X})$ adalah bernilai nol, dan koefisien regresi variabel motivasi $(\mathrm{X})$ bernilai sebesar 0,653 . Hasil analisis regresi motivasi terhadap kinerja karyawan yaitu $Y=3,326+0,653 X$.

Selanjutnya yaitu uji normalitas di sini bertujuan untuk menguji apakah dalam model regresi, variabel terikat dan variabel bebas keduanya mempunyai distribusi normal atau tidak, berdasarkan hasil pengujian normalitas, diketahui bahwa berdasarkan grafik histogram dan grafik P-Plot pola distribusi normal.

Hasil uji yang dilakukan untuk mengetahui signifikan atau tidaknya hasil penelitian dengan mengetahui nilai $t_{\text {hitung }}$ sebesar $9,164>t_{\text {tabel }} 1,667$. Karena $t_{\text {hitung }}(9,164) t$ tabel dengan sig 0,000 $<0,05$. Yang artinya bahwa variabel motivasi berpengaruh secara signifikan terhadap kinerja karyawan PT. Brawijaya Utama Palembang.

Selanjutnya besarnya uji korelasi atau hubungan $(\mathrm{R})$ yaitu 0,741 dari output tersebut maka diperoleh koefisien determinasi (R square) sebesar 0,549 yang mengandung pengertian bahwa variabel bebas (motivasi) terhadap variabel terikat (Kinerja Karyawan) di PT. Brawijaya Utama Palembang adalah sebesar 54,9\%. Dan sisanya 45,1\% dipengaruhi oleh faktor-faktor lain yang tidak diteliti dalam penelitian ini.

\subsection{Variabel $X$}

Berikut ini adalah hasil perhitungaan reliabilitas untuk kuesioner variabel X:

Output SPSS 17.00 tersebut menunjukkan tabel reliability coefficients yang terlihat sebagai cronbach's alpha 0,694 >0,60. Dapat disimpulkan bahwa dari pertanyaan yang merupakan dimensi $\mathrm{x}$ adalah variabel $\mathrm{x}$ adalah realibel.

Tabel 1. Reliability statistics

\begin{tabular}{|c|c|}
\hline $\begin{array}{c}\text { Crocbach's } \\
\text { Alpha }\end{array}$ & N of items \\
\hline .694 & 15 \\
\hline
\end{tabular}




\subsection{Variabel $Y$}

Berikut adalah hasil perhitungan reliabilitas untuk kuesioner variabel Y:

Tabel 2. Reliability statistics

\begin{tabular}{|c|c|}
\hline $\begin{array}{c}\text { Crocbach's } \\
\text { Alpha }\end{array}$ & N of items \\
\hline .734 & 11 \\
\hline
\end{tabular}

Output SPSS 17.0 tersebut menunjukkan tabel reliability coefficients yang terlihat sebagai cronbach's alpha $0,734>0,60$. Dapat disimpulkan bahwa konstruk pertanyaan yang merupakan dimensi variabel Y adalah realibel.

\subsection{Uji Hipotesis (uji t)}

Uji t menunjukan seberapa besar hubungan antar variabel secara parsial terhadap variabel dependen yang dapat digunakan untuk membuktikan hipotesis pertama yang diajukan oleh peneliti. Berikut disajikan output uji parsial dari variabel Motivasi (X) terhadap variabel dependen Kinerja Karyawan (Y).

- Jika thitung $<$ ttabel berarti motivasi tidak berpengaruh signifikan terhadap kinerja karyawan di PT Brawijaya Utama Palembang.

- Jika thitung $>$ ttabel berarti motivasi berpengaruh signifikan terhadap kinerja karyawan di PT Brawijaya Utama Palembang.

Untuk mengetahui ttabel digunakan ketentuan sebagai berikut:

- $\mathrm{a}=0,05$

- $\quad \mathrm{Df}=($ jumlah responde - bilangan konstan $)$ atau $(71-2=69)$

- $\quad \mathrm{t}$ tabel $=1,667$ (hasil dari tabel t pada lampiran)

Berdasarkan tabel 4.10 pengujian statistik dengan metode uji t, dimana tingkat signifikan yang diperoleh $0,000(0 \%)$ dari standar signifikan yang digunakan yaitu $0,05(5 \%)$ dan perbandingan $\mathrm{t}$ hitung dan $\mathrm{t}$ tabel, dimana $\mathrm{t}$ hitung sebesar 9,164 lebih besar dari t tabel 1,667 maka dapat disimpulkan bahwa motivasi mempunyai pengaruh signifikan terhadap kinerja karyawan.

Tabel 3. Hasil uji t (parsial)

\begin{tabular}{|c|c|c|c|c|c|c|}
\hline \multirow{2}{*}{\multicolumn{2}{|c|}{ Model }} & \multicolumn{2}{|c|}{ Unstandardized Coefficients } & \multirow{2}{*}{$\begin{array}{c}\begin{array}{c}\text { Standardized } \\
\text { Coefficients }\end{array} \\
\text { Beta }\end{array}$} & \multirow[b]{2}{*}{$\mathrm{t}$} & \multirow[b]{2}{*}{ Sig. } \\
\hline & & B & Std. Error & & & \\
\hline \multirow[t]{2}{*}{1} & (Constant) & 3.326 & 4.190 & & .794 & .430 \\
\hline & $\mathrm{X}$ & .653 & .071 & .741 & 9.164 & .000 \\
\hline
\end{tabular}

a. Dependent Variable: Y 


\section{Kesimpulan}

Berdasarkan hasil penelitian dari pembahasan pada bab terdahulu, dapat ditarik kesimpulan sebagai beriukut:

- Hasil dari perolehan nilai $t_{\text {hitung }}>$ dari Nilai $t_{\text {tabel }}$ Sebesar 9,164 $>1,667$ dengan nilai tingkat signifikan yaitu $0,000<0,05$. Dapat disimpulkan bahwa variabel independen yaitu motivasi $(\mathrm{X})$ mempunyai pengaruh signifikan terhadap variabel dependen yaitu kinerja karyawan (Y).

- Hasil perolehan koefisien korelasi (R) di peroleh nilai 0,741. Hal ini menunjukkan bahwa korelasi antara variabel independen yaitu Motivasi (X) dengan Variabel Dependen yaitu Kinerja Karyawan (Y) mempunyai hubungan yang "kuat" (74,1\%).

- Dari hasil uji determinasi $\left(\mathrm{R}^{2}\right)$ sebesar nilai 0,549 . Hal ini menunjukkan besarnya kontribusi variabel motivasi bisa menjelaskan variabel kinerja karyawan sebesar 54,9\%. Sedangkan sisanya $45,1 \%$ berkemungkinan dapat dijelaskan oleh variabel lain yang tidak termasuk dalam penelitian ini.

Dari hasil penelitian dapat disimpulkan bahwa motivasi memiliki pengaruh signifikan terhadap kinerja karyawan.

\section{Rererensi}

Edison, E., Anwar, Y., \& Komariyah, I. (2016). Manajemen Sumber Daya Manusia: Strategi dan Perubahan dalam Rangka Meningkatkan Kinerja Pegawai dan Organisasi. Bandung: Alfabeta.

Hasibuan, M. S. P. (2012). Manajemen Sumber Daya Manusia. Jakarta: Bumi Aksara.

Hasibuan, M. S. P. (2013). Manajemen Sumber Daya Manusia. Jakarta: Bu.

Mangkunegara, A. A. A. P. (2011). Mangkunegara. Bandung: PT Remaja Rosdakarya.

Mangkunegara, A. A. A. P. (2014). Manajemen Sumber Daya Manusia. Bandung: PT Remaja Rosdakarya.

Mangkunegara, A. A. A. P. (2015). Manajemen Sumber Daya Manusia. Bandung: PT Remaja Rosdakarya.

Riyadi, S. (2011). Pengaruh Kompensasi Finansial, Gaya Kepemimpinan, dan Motivasi Kerja Terhadap Kinerja Karyawan pada Perusahaan Manufaktur di Jawa Timur. Jurnal Manajemen Dan Kewirausahaan, 13(1). https://doi.org/10.9744/jmk.13.1.40-45

Sedarmayanti. (2013). Manajemen Sumber Daya Manusia: Reformasi Birokrasi dan Manajemen Pegawai Negeri Sipil. Bandung: PT Refika Aditama.

Sutrisno, E. (2014). Manajemen Sumber Daya Manusia. Jakarta: Kencana Prenada Media Grup.

Zainal, V. R., Ramly, M., Mutis, T., \& Arafah, W. (2016). Manajemen Sumber Daya Manusia untuk Perusahaan: Dari Teori ke Praktik (3rd ed.). Bandung: Rajagrafindo Persada. 